This is an Accepted Manuscript of an article published by Taylor \& Francis in The Japanese Political Economy on 14/05/19, available online:

https://www.tandfonline.com/doi/full/10.1080/2329194X.2019.1611376 
Building blocks for the macroeconomics and political economy of housing Engelbert Stockhammer

Department of International Political Economy, King's College, London, United Kingdom engelbert.stockhammer@kcl.ac.uk

Christina Wolf

Department of Economics, Kingston University, London, United Kingdom

c.wolf@kingston.ac.uk 


\section{Building blocks for the macroeconomics and political economy of housing}

Housing played an essential part in the global financial crisis 2007-08 and the Euro crisis. Large parts of bank lending continue to go to mortgages. Housing wealth is the largest part of wealth for most households and is, at the same time, more dispersed than other forms of wealth. House prices exhibit pronounced fluctuations that are closely linked to credit growth. Housing thus plays a crucial role in the macroeconomy, which has become even more pronounced under neoliberalism. We scrutinise different theoretical approaches to housing. Despite its theoretical shortcomings, mainstream economics has pioneered empirical research on wealth effects in consumption and recently documented the role of house prices in financial cycles. Post-Keynesian theory emphasises endogenous money creation, cycles in asset prices and debt, and has formalised the notion of a debt-driven demand regime. Comparative Political Economy research has recently developed the concept of the varieties of residential capitalism, which has different structures of house ownership and housing finance at the core of political coalitions. Marxist political economy has long established the intrinsic link between ownership of land and economic rent and notes that homeownership can act as force of working class fragmentation. Wealth surveys can be used to trace the extent of conflicting interests in a class-relational approach.

Keywords: housing, household debt, finance, real estate prices, class analysis

\section{Introduction}

Housing is an oddly under-researched topic in macroeconomics and political economy. This does not mean there is no research on housing. Quite on the contrary, there are subfields like real estate and housing economics or urban studies which have long paid close attention to issues of housing. But these constitute specialised fields. This may be changing as housing and mortgage finance have gained prominence after the 2008 crisis, where mortgages played a central role. However, in most baseline macroeconomic models, including the mainstream versions as well as the Post-Keynesian (PK) or Marxist versions, there is no housing market. This is surprising, given that housing accounts for 30-50\% of a household's expenditures, 
around $90 \%$ of household debt, and residential investment constitutes approximately half of total investment. Similarly, in political economy, admittedly a heterogeneous field, there was until recently little systematic incorporation of housing. The extensive debates on class analysis, for instance, have sidestepped the issue of working class homeownership.

In the global financial crisis (GFC) 2008 and the Euro crisis housing and housing finance, of course, have played a key role: real estate bubbles were a key factor for the booms that preceded the crisis, derivatives on mortgages and, in particular, subprime mortgage securities were at the epicentre of the early stages of the crisis and their price collapse drove hedge funds into bankruptcy ultimately paralysing the shadow banking sector and, eventually, the entire financial system. While in Europe the subprime securitization featured less prominently, the house price booms and busts in Ireland and Spain were severe. In Britain the bankruptcy of Northern Rock was due to its aggressive growth, mostly in mortgages. Thus since the crisis 2008 there has been a strong growth in interest in the role of housing and housing finance, and a reconsideration of the how financial systems operate more generally.

The GFC has led to dynamically growing analyses of the various impacts of housing and housing finance ranging from historical analyses of the composition of credit (Jordà, Schularick, and Taylor 2016), the impact of housing wealth vs financial wealth on consumption expenditures, the impact of housing vs business credit on growth (Bezemer 2014; Bezemer, Grydaki, and Zhang 2016), analyses of the drivers of household debt (Stockhammer and Wildauer 2016) and housing in political economy (Aalbers and Christophers 2014a).

This paper surveys a rapidly growing literature in the field of macroeconomics and political economy of housing and housing finance. The aim of the paper is, first, to review the literature on the impact of housing, mortgages and real estate prices on macroeconomic 
growth and stability and to assess to what extent different economic paradigms can account for the stylized facts. Second, we review the literature on the impact of housing structures on political attitudes and class structures and assess how different approaches can explain these. Third, we apply a class-based analysis to the UK wealth and asset survey with the aim to delineate a future empirical research agenda combing political economy and macroeconomic approaches.

Our review suggests the following stylized facts that different theories have to explain: mortgages are the largest components of household debt. Real estate prices reveal both increases over the last decades and a cyclical pattern, with a cycle length well beyond regular business cycles. Changes in household debt have become an important driver of growth and the level of household debt is a predictor of the severity of recessions. Periods of rising house prices often do not come with a spread homeownership implying that the increase in house prices will have distributional effects. There is some evidence that homeownership impacts on political attitudes, in particular regarding the welfare state. Homeownership is strongly related to income distribution.

The paper is structured as follows: section 2 discusses analyses of housing and housing finance from economic and financial history. Sections 3 and 4 surveys the contributions of mainstream economics and post-Keynesian theory on the topic. Section 5 reviews models of house price cycles. Section 6 and 7 cover Comparative and Marxist Political Economy respectively. Section 8 discusses the housing in the UK from a class-analytic perspective. Finally section 9 concludes. 


\section{Economic and financial history}

While economic history has long-standing concern for corporate finance, in particular the finance of industrialisation most financial histories do not cover housing finance.

Kindleberger's (1993) seminal Financial History of Western Europe has several index entries for mortgages, but these refer mostly to agricultural mortgages rather than household credit. Similarly, in one of the early books on financialisation, Arrighi (1994) takes a long historical view, where financialisation features in the long downswing of the hegemonic power losing industrial leadership but maintaining financial dominance. He discusses industrial finance and government debt, but not household debt or mortgages.

It is only very recently that more systematic histories of housing and housing finance have been written. These point to at least three important shifts in housing finance and house price dynamics, which need to be explained by macroeconomic and political economy theories. Firstly, Blackwell and Kohl (2018) and Kohl (2018) give an overview of the history of mortgage credit institutions. These differ in important ways from the banks that deal with businesses. In particular the market/bank-based distinction does not apply in this form to mortgages. The Scandinavian and Germanic countries developed forms of mortgage securitisation that allowed specialised institutions to emerge that sold on mortgages in the form of covered bonds, i.e. they remained on the banks' balance sheets. Jorda et al (2016) document the secular increase in mortgage lending as share of bank balance sheets. They report declining share of mortgages as share of total bank lending until the World War I, an increasing share in the interwar period that consequently collapses, and then sustained rise of mortgage credit after World War II, which accelerates after 1980. While in 1900 around one third of loans were non-mortgages, by 2000 the share was two thirds (Jorda et al 2016, Figure 4). Knoll, Schularick, and Steger (2017) present data on real house prices, which show that, fluctuation notwithstanding, real house prices were relatively stable until World War II and 
begin a secular increase (with larger fluctuations) since then. The following sections review the ability of different approaches to macroeconomics and political economy to account for both the emergence of these trends and their effects.

\section{Mainstream macroeconomics}

Mainstream macroeconomics has lacked a systematic treatment of debt and assets. At the core this is related to strong role of assumptions of rationality and life cycle optimisation behaviour. This is has ruled out interest in speculative asset prices movement and often in a separation of the discussion of financial and 'real' issues. Real issues are about technology shocks, which give the impetus for real business cycle theory (RBC) and are still at the core of modern DSGE model, which are essentially RBC models with nominal rigidities. The assumption of rationality and perfect foresight also ruled out an analysis bankruptcies.

In the background of these models is a loanable funds theory of financial markets, where lending is understood as a use of saving and saving a (positive) function of the interest rate. This is at odds with Keynesian understanding (saving depending on income) and modern theories of endogenous money creation (where loans create deposits). It also focuses on net lending and tends to regard households as the surplus (saving) unit and firms as the deficit (borrowing unit). In fact, the lending boom of the 2000s was driven by household borrowing (and financial sector borrowing) and was gross lending.

The neoclassical literature on housing is theoretically uninteresting. Housing is seen as a 'standard commodity' (Fallis 1985, 34), the demand for which is determined by relative prices of other goods and households' budget constraint stemming from their labour-leisure trade-off. The supply of housing follows a standard Cobb-Douglas production function, land being one among other capital inputs and paid at its marginal product. Investment decisions then, reflect producers' time discount rate (equal to the market rate of interest) and price is 
determined by the forces of demand and supply (Fallis 1985).

Mainstream macroeconomics is divided into New Classical and New Keynesian streams. The New Keynesian approach accepts the need for microfoundations based on optimising behaviour, but questions whether markets are always clearing given market imperfections like transaction costs or asymmetric information. That gave rise to Stiglitz and Weiss (1981) model of credit rationing, which is still a benchmark model and informs the financial accelerator model (Bernanke, Gertler, and Gilchrist 1999). The Stiglitz model, notably, is a model of rationing credit to businesses, i.e. it is about corporate credit, not mortgages. The financial accelerator model and the related lending channel literature emphasise that net worth will affect the value of collateral and thus access to credit. Therefore banks will want to restrict lending if they have balance sheet problems. In the New Keynesian setting (i.e. with information asymmetries), credit constraints matter for macroeconomic outcomes. In an NK DSGE model with two types of households that differ by their rate of time preference Eggertsson and Krugman (2012) show that episodes of what they refer to a 'Minsky Koo debt deflation' can arise, but the model neither has a proper financial sector nor are financial crises endogenous.

However, despite the theoretical limitations of the mainstream models, mainstream policy institutions did generate a substantial amount of empirically or policy-driven research. In particular central banks and the OECD were leading the empirical literature on wealth effects (Boone, Giorno, and Richardson 1998; IMF 2000). This literature was motivated in the 1990s by the declining saving rate of US households, which from a neoclassical perspective would depress long-run growth (Maki and Palumbo 2001). In the 1990s, however, it came with relatively high levels of growth. A sizable literature emerged that highlighted the role of increasing wealth as a cause of increasing consumption. Initially, the focus was on financial 
wealth and equity prices in particular, as the 1990s were a period of sustained equity price inflation, which eventually ended in the dot.com crash of 2000. However, while equity prices collapsed in 2000 and remained subdued thereafter, consumption expenditures held up, which lead to the realisation that housing wealth is typically (at least in the Anglo-Saxon countries) more important for consumption as homeownership is widespread and real estate is good collateral (Case, Shiller, and Quigley 2005; Slacalek 2009).

That said, the empirical literature on wealth effects fits somewhat uneasily within the rational foresight model, which is reflected in that literature. First, it is not clear whether housing wealth in such a model is wealth at all (Buiter 2010). Second, there is a tension between theory and the empirical approach in these papers. In their theory sections the empirical wealth effects papers refer to rational actor/perfect foresight models and then estimate consumption equations that react to market prices. In other words, perfectly rational individuals in, say, Ireland, observe a sharp increase in real estate prices and act on it as if it were a fundamental increase in real estate values, i.e. the perfectly rational individuals never worry about the possibility of a bubble even in the face of spectacular price increases.

Especially after the crisis there was an assessment of the impact of real estate prices on credit availability. Among the most impressive of these is a series of papers by Mian and Sufi who use fine-grained survey data to document how the decline in house prices affected US households across regions (Mian, Rao, and Sufi 2013) and argue that credit supply shocks explain much of the housing bubble (Mian and Sufi 2018). Several authors at the critical edge of the New Keynesian mainstream have made the case that lending and house prices can reinforce each other to give rise to bubbles (Muellbauer 2007; Goodhart and Hofmann 2008), however without turning this into a full theory of endogenous cycles.

Since the crisis, it is fair to say, this critical research on financial instability and the long-term 
growth impact of finance has turned into sizeable stream, even if it presses ahead without adequate theory. Aizenman and Jinjarak (2014) provide evidence that capital flows have a powerful effect on real estate prices (see also: Badarinza and Ramadorai 2018). Arcand et al (2015) provide evidence that finance has negative effects on growth beyond a certain threshold, namely when private debt reaches $100 \%$ of GDP. This represents a major departure from the dominant view that financial deepening has a positive impact on growth (Levine 1997). Borio (2012) and Barrell et al. (2010) document that house price inflation is a leading indicator for financial crises. Drehman, Borio, and Tsatsaronis (2012) and Aikman, Haldane, and Nelson (2015) provide evidence for the existence of financial cycles, which is inconsistent with the notion that financial crises are due to exogenous shocks. These financial cycles are longer than regular business cycles.

What emerges from this brief survey of mainstream economics is a tension between a theoretical framework that, with its rationality and market clearing assumptions, is ill-suited to explain recent dynamics and crises emanating from the real estate sector, and at the same time a dynamic empirical research programme that bypasses the rigidities of the theoretical framework.

\section{Post-Keynesian economics}

Post Keynesian economics (PKE) does not employ the life time optimising assumptions of neoclassical economics. Rather it assumes given marginal propensities of consumption that will differ by class position or by the position within the income distribution. To some extent PKE has suffered from the relatively independent advancement of its Kaleckian and Minskyan stream. As the basic Keynesian model assumes autonomous consumption, this implies that if there are demand shocks, of which there are plenty in a Keynesian economy, 
parts of the population (presumably the poor or those with illiquid assets) will have to accumulate debt in order to accommodate to the resulting income declines while autonomous consumption stays constant. Despite the fact that there is a logical role for household borrowing in PKE, it has not traditionally played an important role. Nor has housing. The PKE class model seems to implicitly have been interpreted as one where workers not only do not have property in the means of production, but also none in the means of reproduction, which includes housing. We will return to this issue in section 8 . Wealth effects do not feature prominently in PKE (until the development of SFC models) as they were historically associated with the neoclassical and Monetarist criticisms of Keynesianism.

There are five debates where household debt and, ultimately, housing does enter. First, Palley (1994) and Dutt (2006) proposed models of working class household debt. The poor are borrowing from the rich, which will have positive short-term effects on consumption (as finance is made available to those with high marginal consumption propensities), but negative longer term effects as interest payments distribute income towards those with high savings propensities. These models are focussed on consumer debt and do not treat housing explicitly. Second, an important innovation in PKE has been the development of stock flow consistent (SFC) models. These track all flows and stocks in a macroeconomic model and enforce consistency between the two. In these models economic sectors are thought of in a balance sheet context and assets and liabilities will enter behavioural equations. Godley and Tobin have pioneered these models and Godley has repeatedly highlighted that economies are anchored in stock-flow norms. If one assumes that consumption depends on disposable income and some measure of wealth, this implies that households will attempt to reach a target wealth-to-income ratio (Godley and Lavoie 2007, 75). If wealth increases beyond the target ratio, households will consume that 'excess wealth'. As housing wealth is the most important wealth component for households, borrowing in order to realize real estate capital 
gains would be the result. Indeed, Godley (1999) had warned early that rising US household debt would be unsustainable. Third, in the demand regimes literature, which began as an operationalisation of the Bhaduri-Marglin framework, there was a recognition that some of the actual neoliberal growth models were relying heavily on the growth of household debt, which fuelled consumption growth (Stockhammer 2012; Lavoie and Stockhammer 2013). While some authors suggest that rising income inequality has been the main driver of household debt (Kapeller and Schütz 2014; Perugini, Hölscher, and Collie 2016), Stockhammer and Wildauer (2016) present evidence that real estate prices are the main cause. Fourth, while Minsky (1978) focussed on business debt rather than household debt, the notion of endogenous financial instability has also been applied to the household sector. Ryoo (2016) presents model of housing cycles that is driven by non-linear expectation of house price inflation (such as in Dieci and Westerhoff 2012). Fifth, with close reference to the financialisation debates (see below), several authors have suggested that increased lending in the neoliberal era would result in higher volatility rather than higher growth. Bezemer et al. (2016) analyse lending decisions of banks and highlight the distinction between nonfinancial credit and asset market credit. Real estate transactions are an example for the latter (but it also includes credit to financial institutions). Bezemer et al. (2016) argue that the two types of credit have different demand and growth effects. Arestis and González (2014) is one of the few PK papers that explicitly model the housing sector in a macro model. They propose a model of the supply and demand for housing based on PK endogenous money theory. The model allows for private sector borrowing derived from real estate transactions, however it does not explicitly model business and household borrowing decisions separately.

We found that PKE with it basis in conventional behaviour and pro-cyclical animal spirits and its theory of endogenous money creation is better equipped to analyse financial cycles and crisis, but it has been slow to apply this framework to housing. There are several 
noteworthy rigorous empirical studies on debt-driven growth models and the differential impact of business credit and mortgage and financial credit, but overall PKE has not translated into an empirical research programme on housing.

\section{Models of house price cycles}

Overall it is surprising how few macroeconomic models of house price cycles there are. There is strong evidence of financial cycles (Drehmann et al 2012; Aikman et al 2015), which typically find that house prices are a key component of these cycles. Glaeser (2013) documents the long history of real estate speculation in the USA. House price inflation also performs well in tests of early warning systems for financial crises (Barrell et al. 2010). The positive feedback loop between house prices and credit is well established (e.g. Arestis and González 2014). But still, given that most macro models fail to include the housing sector, even fewer model house price cycles, with some exceptions that are grounded in PKE, behavioural economics or heterogeneous agents modelling. Dieci and Westerhoff (2012) present a model of the housing market where endogenous price cycles emerge from the interaction of actors with fundamentalist and those with momentum-based expectations, however, they do not offer a full macroeconomic model. On the PKE side, Ryoo (2016) presents a model where household form extrapolative expectations about house price increases and use increased borrowing to finance consumption, which drives the boom. Assuming a non-linear expectation function eventually the bubble bursts. Bofinger et al. (2013) extend a NK DSGE model with a monetary policy rule to include a housing market. They build on De Grauwe (2012) who had introduced fundamentalists momentum trader dynamics in a full macro model with heuristics and learning. Bofinger el at apply this to the housing sector and show that the fundamentalist momentum trader interactions can generate 
cycles.

While house price cycles can be modelled, changing trends over time such as the increase in mortgages as share of bank lending or increases in the frequency and magnitude of house price fluctuations observed by economic historians (see section 2) call for an incorporation of political and institutional factors. This bridge is offered by political economy approaches. The next two sections review Comparative Political Economy (CPE) and Marxist political economy approaches to housing respectively.

\section{Comparative Political Economy and the financialisation debates}

Comparative Political Economy (CPE) is an emerging field that is informed both by economics, in particular the classical school and Keynesian traditions, and by social sciences, in particular political science (Clift 2014). Finance and housing have not featured centrally in this field until recently.

Within CPE the Varieties of Capitalism (VoC) has been particularly influential because it managed to integrate previous insights in the differences in labour relations, welfare systems and financial systems. It emphasises substantial differences in national capitalisms. The central reference point in establishing those varieties of capitalism is how they achieve competitiveness. The most famous distinction of $\mathrm{VoC}$ is between liberal and coordinated market economies. The focus on competitiveness has implied a focus on corporate finance (as opposed to housing finance) and a functionalism (the financial sector is analysed as providing finance for business rather than being the origin as financial crises). The widely used distinction within financial systems between market and bank based systems stems from the analysis of corporate finance. 
Some of the CPE literature does not adhere to the VoC framework and gets closer to PK growth models, showing that credit growth sustains demand regimes and welfare provision increasingly relies on housing and housing finance. Crouch (2009) has coined the term ‘privatized Keynesianism', arguing that original Keynesianism relied on government intervention and thus public debt to stabilise the economy and consumers' expectations. This has since the 1980s been replaced by a regime, where credit is provided to household by commercial banks and other lenders. Crouch cites rising levels of mortgage debt as evidence and argues that in some countries, namely the UK, this turned into an effective policy regime, but he does not offer a systematic comparative analysis. Crouch does not discuss the fact that private lending tends to be pro-cyclical (in contrast to Keynesian deficit spending, which is counter-cyclical) but highlights that "financial firms and entrepreneurs developed forms of knowledge that encouraged eventually self-destructive decisions" (Crouch 2009, 393). Watson (2010) makes a similar argument and uses the term 'house price Keynesianism', which (again for the UK) he situates it in the context of a move towards asset based welfare. Watson (2010) analyses the impact of house prices and mortgage debt on the subjectivity and identity of households and also highlights the cyclical nature of house prices.

Parts of the CPE literature emphasise political implications of homeownership. Schwartz and Seabrooke (2008) propose a theory of varieties of residential capitalism. Unlike the original VoC approach competitiveness is not a reference point in their analysis (presumably because the national housing markets do not compete internationally). Rather they offer a rich classification of the political economy of homeownership and housing finance. Based on the systems of housing finance and homeownership rates, they distinguish between corporatist (high mortgage debt and low ownership; Germany, Netherland, Denmark), liberal (high mortgage rates and high ownership; UK, USA, Australia, Norway), statist developmentalist (low mortgage and low ownership; Austria, France, Japan, Sweden) and catholic-familial 
(low mortgage and high ownership; Belgium, Italy, Ireland, Spain). They emphasise the political economy implication of these regimes: home ownership tends to undermine the viability of large welfare states, in particular public pension systems (the requirement of high down payment conflicts with the ability to pay higher taxes); high ownership rates will make it more difficult to find majorities to pass rent control laws and provide public housing. This is confirmed by Ansell (2014), who based on US and UK survey data finds econometric evidence that homeownership in the presence of house price appreciation is negatively correlated to individual preferences for redistribution and social insurance systems. Yet, Schwartz and Seabrooke's analysis is static in describing the interaction of housing structures and political majorities as well as some institutional complementarities. In contrast, financial crises or house prices cycles do not feature.

Blackwell and Kohl (2018) provide a history of housing finance. They offer a classification based on the distinction a deposit- based bank system, a mortgage bond-based bank system, state-based and a peer-based lending system. They provide historical evidence and a historical explanation, which extends Gerschenkron's theory of late industrialisers, but with quite different results. In particular they argue that some patterns of corporate finance are inverted for housing finance. The early industrialisers developed deposit-based mortgages, i.e. a form of bank-based systems. In contrast, late comers like Scandinavian and Germanic countries developed a form of mortgage finance that is more market-based in that it relies on mortgage securitization. Extreme late-comers typically relied on state-based systems. Kohl (2018) argues that higher mortgages do not necessarily lead to higher homeownership rates based on a historical review since the late $19^{\text {th }}$ century and econometric analysis for the postwar period. Thus mortgage growth is neither necessary nor sufficient for homeownership. Kohl, more than the other CPE literature speaks directly to the cyclical nature of house prices and the house price-mortgage debt loop. 
In the financialisation debates, issues of housing come relatively late, that is in the 1990s. Initial debates on financialisation focussed on financial liberalisation, in particular in developing economies, and on corporate governance and shareholder value orientation, i.e. the financialisation of businesses rather than households. These emphasised the potentially negative effects of financialisation on growth and the business cycle and its distributional implications. However, by the late 1990s and early 2000s the financialisation of households and the rise of household debt featured more prominently. Langley (2007) highlights the changing subjectivities stemming from the increased financial involvement of households. These include in particular the rise of mortgages and private pension provision. Erturk and Solari (2007) highlighted the shift in bank balance sheet from lending to businesses towards lending to households, i.e. mortgages, and fee generating activities (i.e. investment banking activities). Changing historical trends in housing markets observed by economic historians (see section 2) are thus located in the wider phenomenon of financialistion by this stream of literature.

Much like in macroeconomics, housing has been a side issue until recently. In the last few years research on housing has left the $\mathrm{VoC}$ framework behind and investigated the political impact of homeownership, in particular on attitudes towards the welfare state and the pension systems and borrowed from Keynesian analyses of debt. A core tenet of CPE rests on the two-way relationship between housing and policy regimes: housing and housing finance systems are shaped by policy regimes and policy regimes are themselves influenced if not reducible to housing interests. While there are several useful contributions a unified CPE approach to housing is not yet discernible. 


\section{Marxist Political Economy}

Marxist political economy approaches the question how and to what extent housing has restructured systemic dynamics of accumulation through conflicting interest around ownership of land and real estate and the mediation of these conflicts through the state and through the market. As for the other schools of thought it is striking that housing appears in niche debates rather than constituting an integral part of their core theory (such as Shaikh 2016). The theorisation of social relations of land-ownership builds on the concept of land rents and power of land-/ property-owners to extract payment from non-owners (Aalbers and Christophers 2014a; Aalbers and Christophers 2014b; Berry 2014). Debates over the origin of land rent in the urban context are theoretically unsettled (Harvey 1974; Park 2014; Basu 2018). Yet, there are a number of points of agreement, in particular the collective nature underlying increases in land values, the value of land being enhanced, for instance, by public spending on infrastructure, or ultimately collective processes like the emergence of production agglomerations or urbanisation processes more widely (Harvey 1974).

The conceptualisation of housing around rent allows for two things. Firstly, it establishes contradictions of wealth accumulation based on rent appropriation. Rent is a benefit derived from the exclusive possession of a factor of production in excess of the production cost of that factor, and is therefore an unearned windfall income to be distinguished from productive activity and profits (Ryan-Collins, Lloyd, and MacFarlane 2017). The value of land not being directly related to investment the owner of land has put in the land but, instead, determined socially, makes ownership over this scarce if man-made asset a means of rent extraction. If hardly proposing a new insight, Marxists are more explicit about the fact that housing and land cannot form a long-term basis for wealth accumulation. For value to be appropriated it has to be created somewhere and "If all capital chases rent and no capital goes into production, then no value will be produced out of which the transfer payment that rent 
represents can come.” (Harvey 1974, 241) In the Marxist reading, for capital gains to be realised on land and real estate, prices of land and real estate have to rise faster than the general price level. Since rising house prices will eventually be passed down into rents, rents paid by tenants will rise faster than inflation and wages (Berry 1986; Edel 1982). Increases in disposable income outright owners enjoy in the absence of rent payments rely on the same conditions. This, in turn, implies limits to property-based wealth accumulation and wealth effects.

Secondly, it allows establishing class-interests opposed to one another. Ownership of housing and real estate can be related to the appearance of conflicting housing-related interests, which cross-cut basic class divisions. Classes in the orthodox Marxist reading are understood as antagonistic interests between workers and capitalists, other struggles being contained within and organised around these boundaries. The concrete manifestations of interests, class tactics and alliances cannot, however, be mechanically derived from these two abstract categories but will depend on particular historical conjunctures expressed politically and ideologically (Poulantzas 1982). An important element in tracing the concrete manifestations of interests and potentially alliances with sections of other classes is the process of class fragmentation. Class fragmentation can have different origins, but a limited number of contributions identify housing as an important driver of working class fragmentation (Berry 1986; Harvey 1982). While Saunders (1984) treats housing-related interests as undermining the usefulness of the capital labour divide, Berry points out that access to owner-occupation is income determined and therefore itself determined by labour market outcomes. When fragmentation occurs within classes this can generate significant income inequalities within classes and lead to overlap in income levels across class boundaries. This does not necessarily mean that common interests transcending traditional class boundaries form, but there is likely going to be intra-class conflict to protect and extend these income shares. Therefore, the promotion of 
property ownership among workers ultimately serves capitalists in that it establishes workers' allegiance with the principle of private property (Harvey 1982) and that it can drive homeowners to defend their privileged position in the workplace against the interests of other workers (Berry 1986).

Harvey (1974) locates housing-related class interests in conflicting interests between landlords and low-income tenants as well as between speculator-developers and middle classes. He emphasises that the balance of power between these different classes needs to be examined together with supportive political institutions. The state, following multiple sets of logic often at the same time, plays a crucial role in creating, recreating, changing and restricting development of housing markets thereby tipping the balance of power between different housing related interest groups.

Both CPE and Marxist political economy provide important bridges to other social sciences that help account for institutional and political factors behind observed correlations between housing and macroeconomic aggregates and changes to trends over time. CPE has been successful in establishing patterns from a comparative perspective, documenting the complementarity of homeownership and welfare regimes, and elaborating political aspects of debt-driven growth models. A distinctive feature of Marxist approaches is that they regard social outcomes as shaped by class structures and conflict based in production relations. Homeownership thus represents a fragmentation of the working class, which impacts on its bargaining position. However, Marxists have been slow to take this class- and rents-based approach to housing forward empirically in terms of linking it to political attitudes and macroeconomic dynamics. 


\section{Exploring housing in a class-relational approach based on wealth survey - an illustration from the UK}

To illustrate the relevance of these points (i.e. contradiction of rent-based accumulation and conflicting housing-related interests) but also the challenges in taking these points forward empirically, we briefly turn to the example of the UK. Here, several housing-related policy shifts have promoted real estate as a means of wealth accumulation, investment opportunity and insurance against dwindling wages, pensions and welfare provision. These policy shifts had a substantial impact on macroeconomic outcomes including household debt, house prices and financial instability (Fernandez and Aalbers 2017). Yet, they also contributed to the appearance of conflicting housing-related interests, which cross-cut basic class divisions and changed the accumulation dynamics among firms.

Firstly, from the early 1980s onwards UK housing policy shifted away from subsidies for the supply-side through state sponsored housing development towards demand-side incentives with the aim of helping individuals to either buy or rent (Ryan-Collins, Lloyd, and MacFarlane 2017). Secondly, since the late 1970s around half of the UK's public estate was privatised, equivalent to $10 \%$ of British land mass (Christophers 2018). Finally, financial deregulation was a significant counterpart of the Thatcher government's promotion of demand for owner-occupied housing as a means to widen access to private mortgage finance (Wood 2017; Hasan and Taghavi 2002).

These policy shifts have strengthened class interests emphasised by Harvey 1974, in particular those of speculator developers tied to finance capital and those of landlords more generally. They favoured monopolisation and speculation in the developer market, smaller developers being driven out of the market since social house building did no longer act as counter-cyclical force to the business cycle. The release of public land, in turn, served larger 
developers to engage in speculative land banking (Christophers 2018). The growth in the supply of houses reduced substantially, annual housing completion being less than half their peak in 1968 by 2013. This, coupled with increased demand acted as a driver of substantial house price increases in the UK since the late 1980s (Ryan-Collins, Lloyd, and MacFarlane 2017). Private landlordism increased since the 1990s and intensified after the GFC (Kemp 2015) becoming, in fact, a wealth accumulation strategy (Soaita et al. 2017).

The housing related policy shifts are also likely to have contributed to working class fragmentation into non-property-owning-working class and property-owning-working class as theorised by Berry (1986). Based on the first five waves of the UK Wealth and Asset survey (WAS) (Office For National Statistics 2018), Arundel (2017) has empirically established housing as the major driver of wealth inequality in the UK. The WAS can be taken further to trace inequalities specifically in a class-relational approach treating them as coming out of antagonistic interests between and within classes, mirroring an approach pioneered by Fessler and Schürz (2018). This can serve as a starting point to map the potential importance of antagonistic housing-related interests within classes.

Fessler and Schürz (2018) distinguish between renters, owners and capitalists. They maintain that these ownership structures imply unequal power relationships between classes and drive inequality, with a very clear concentration of renters in the first three deciles of the income distribution, a concentration of owners between the fourth and eighth decile and a concentration of capitalists among the two wealthiest deciles both in the US and in the Euroarea.

However, different ways to delineate intra-class fragmentation and conflict are possible. In what follows, we define housing-related class fragmentation as antagonistic interests between renters, outright owners, mortgage owners and rentiers, including the latter to account for the 
Marxist emphasis on rents emanating from housing. Renters are all those who report to rent their main residence. ${ }^{1}$ Outright owners are those who report to own their main residence without mortgage and do not derive any rental income. Mortgage owners are those who report to own their main residence with mortgage but do not derive any rental income from other property. Rentiers own their main residence with or without mortgage and also own other land or real estate such as buy to let properties from which they derive rental income.

Owner-occupiers have an interest in increasing house prices to realise capital gains on their property wealth. Yet, property values being loosely correlated to rent prices, this is diametrically opposed to the interests of renters. Politically, this could play out in opposing interests around new housing development. Though not explicitly pursuing a Marxist classrelational approach, Coelho et al (2017), trace political conflict between homeowners and voters with interests in social housing. Vested interests of existing home-owners for prices increases influence planning decisions, the housing stock growing significantly less in local authorities with higher proportions of owner-occupiers among local households.

Mortgage owners, have, in principle similar interests to those of outright owners though their behaviour in the workplace might be very different. Mortgage owners depend on bank finance and are, in the face of rising house prices, heavily dependent on keeping their employment and also to remain in high-paid positions (Kim, Tadeu Lima, and Setterfield 2017). Harvey (1982) sees this as the ultimate way to discipline workers' militancy. They are thus likely to be ready to defend their privileged position in the workplace, possibly against

\footnotetext{
${ }^{1}$ There were 111 cases, in which the primary residence was rented but rental income derived. For 82 of these rental incomes derive from BTL or land overseas or other property and they were classified 'rentier'. The remaining 29 cases did not own property of any sort nor have mortgages, some even deriving benefits. Their rental income might derive from peer-to-peer renting schemes. They were classified as renters.
} 
the interests of non-property owning workers. The outright-owning working class, by contrast, is to an extent de-commodified by housing wealth, notably through the higher disposable income they enjoy in the absence of rent payments. Finally, rentiers, rely for a part of their income on rental income. They therefore have an active interest for there to be a pool of (low-income) tenants with no alternative to private-renting. This is likely to be mirrored in an opposition to social housing but could also be expressed in support for precarious forms of employment like zero-hour contracts.

Table 1 summarises the proportions of these different tenure classes within the sample. The WAS (Office For National Statistics 2018) surveyed 18,611 households, which with appropriate weights add up to 25.6 million households, hence representing the total number of households in the UK. Of these, $32.7 \%$ are renters. Outright owners and mortgage owners account for roughly $30 \%$ of households each. Finally, there are a non-negligible number of UK households who derive rental income from property, in total 1.6 million households, i.e. $6.4 \%$ of households.

Table 1 about here

It is noteworthy, that mortgage owners and rentiers are overrepresented in managerial and professional occupations. This particularly pronounced for rentiers, $62 \%$ of which report to pursue managerial occupations. By contrast, Renters are overrepresented in routine and manual occupations $(50 \%)$ though roughly one third of outright owners also report to pursue or have pursued this type of profession (Table A1 in the Appendix). Yet, $88 \%$ of outright owners are older than 55 . By contrast, $65 \%$ of renters, $81 \%$ of mortgage owners and $52 \%$ of 
rentiers are younger than 55 (Table A2).

We find substantial differences in total annual household income, employment income and pensions between the different housing statuses, mean income being lowest among renters $(£ 23,465)$, followed by outright owners $(£ 32,214)$. The highest average annual incomes emerge among the rentiers $(£ 63,479)$. Note that while these differences are driven by labour market outcomes (employment income of rentiers for instance being nearly twice that of outright owners and around three times that of renters when excluding pensioners), income from rent accounts for substantial parts of income of rentiers. Average annual rental incomes of rentiers $(£ 13,061)$ are in the same order of magnitude as renters’ average employee incomes (£12,861) (Table 2). Rental incomes represent 41\% rentiers’ of employee incomes (31\% when excluding pensioners) and $21 \%$ of their total average annual income. Notice that these rental incomes largely exceed any income derived from investment, rental incomes being around four times higher than investment income (calculations based on Table 2). In short, there appears to be a group of high income earners who actively play the housing market and derive substantial parts of their total income from rental payments.

Table 2 here

This allows for three observations. Firstly, we note that housing outcomes are correlated with income level and occupational groupings, which supports class-analytic approaches. The fact that housing outcomes appear to be correlated to labour market outcomes, raises the question of causality. It can be interpreted as housing outcomes reflecting capital-labour relations (as in Berry 1986). Yet, in line with Fessler and Schürz, housing outcomes may also reinforce 
inequality through rent payments received by rentiers, capital gains and availability of housing capital and collateral. Second, homeownership is wide spread, which implies that substantial parts of the working classes are homeowner. This poses some challenges for Marxists approaches that originally conceived the working class without substantial wealth (and thus forced to sell their labour power), but makes arguments of class segmentations more relevant. Third, an open question is whether there is a real anchor for house prices (and thus capital gains) or whether they are driven by financial factors and speculative dynamics. From a Marxist viewpoint for increases in capital gains on real estate to occur, rents paid by tenants must rise faster than prices and wages. This implies a limit to how far property prices can rise and hence limits to housing based wealth accumulation. In contrast in the PK view, expectations about the future and credit availability are the key factors determining real estate prices. That implies that there is no real anchor, but cyclical speculative dynamics.

In the course of the last boom the system pushed towards social limits. Strikingly, for private renters in the lowest two income deciles, net rent (excluding utility payments) constitutes $41 \%$ and $37 \%$ of households' disposable income respectively (Table 3 ). ${ }^{2}$ These figures increase to $57 \%$ and $45 \%$ when including utilities payments (Table A4). By contrast, outright owners spend only between $5 \%$ and $23 \%$ on housing related costs. Hence the implications of owning versus renting a home on household budget are substantial.

Table 3 here

\footnotetext{
${ }^{2}$ For this we base our calculations on the UK Living Costs and Food Survey, 2016-2017 (Department For Environment and Office For National Statistics 2018). See Table A3 for distribution by tenure.
} 
The challenge remains to establish antagonistic interests empirically not just conceptually. From the above we identify the following open empirical questions. Firstly, how does working class fragmentation play out in the workplace and how does it translate into political attitudes? Secondly, how do shifting class relations (working class fragmentation and strengthening of rentiers) correlate to macroeconomic aggregates, namely debt and consumption? How do the antagonistic interests between renters and rentiers play out politically and ideologically?

Indeed, empirical scholarship on housing-related class interests is scarce. Emphasis, so far, is rather on discourse and social norms than capital-labour relations. Wood 2017 demonstrates that housing-related institutional shifts have created structural conditions that shape agency by transforming private home-ownership and mortgage-led accumulation into a dominant social norm in the UK. Hancock and Mooney (2013) show that the working class relying on social housing is stigmatised in the UK, their reliance on social housing said to be the consequence of irresponsible and disorderly behaviour, which serves to regulate and control working class communities.

\section{Conclusion}

So far housing has been given little consideration in the core of macroeconomics and political economy. This is despite growing evidence of the importance of housing for economic activity and in particular the central role of household and mortgage debt for financial crises. But even in normal, i.e. non-crisis times, housing related expenditures constitute a large amount of household budget and around half of residential investment. Housing has been 
explored in subfields and academic niches. This paper has thus reviewed mainstream macroeconomics, PKE, Comparative Political Economy and Marxist Political Economy. For each of these we find some insight, but the balance between theoretical advances and empirical advances is uneven. Mainstream economics, because of its rationality and market clearing assumptions, has a limited ability to conceptually understand the dynamics emanating from real estate markets. Still it has provided a substantial amount of the empirical research on wealth effects and, more recently, evidence on financial cycles. PKE is much better positioned to analyse housing finance as it has endogenous money creation and financial instability at its core, but it has been slow to provide empirical applications. Political Economy approaches have also proceeded unevenly. Like mainstream economics the VoC approach is ill-suited to understand the complex dynamics arising from housing because of its focus on supply-side factors and competitiveness. However, other parts of Comparative Political Economy have advanced research on housing, inspired by the financialisation literature and PK analysis of growth models. It has also, with a heavy dose of institutionalism and economic history, motivated a comparative research on mortgage finance systems. Marxist Political Economy highlights rentierism and (intra)-class conflict. Using asset and wealth surveys in a class-relational approach can be a useful starting point in tracing power relations and the pervasiveness of antagonistic (intra)-class interests. For the UK, for instance, some $6 \%$ of households deriving on average as much as one fifth of their total annual income from rental payments. However the challenge lies firstly in defining theoretically grounded delineations when class boundaries are themselves unsettled and secondly in taking the class-relational approach to housing forward empirically, in particular linking potential housing-related class fragmentation to capital-labour relations as well as macroeconomic aggregates.

Short, an adequate macroeconomics and political economy of housing remains to be 
developed. It will have to build on PK macroeconomic theory to understand the debt dynamics emanating from the housing sector, but incorporate mainstream quantitative methods. Its impact is large, both on macroeconomic dynamics, where it has powerful influence on investment and consumption, but also on financial stability as mortgage debt constitutes most of household debt and an increasing share of bank balance sheets. House price dynamics tend to have a positive feedback on credit (as housing is used as collateral) and thus is prone to speculative bubble. Housing has a powerful impact on political dynamics in that it can shape identities and political preferences, political economy approaches finding negative correlations between homeownership and support for redistribution and social insurance as well as new housing development. It raises interesting questions for class analysis, as parts of the working classes do own their homes (often they also owe a lot of mortgage debt), which can affect their social identify as well as their political orientation. 
References

Aalbers, Manuel B., and Brett Christophers. 2014a. 'Centring Housing in Political Economy'. Housing, Theory and Society 31 (4): 373-94. https://doi.org/10.1080/14036096.2014.947082. . 2014b. 'The Housing Question under Capitalist Political Economies'. Housing, Theory and Society 31 (4): 422-28. https://doi.org/10.1080/14036096.2014.947083.

Aikman, David, Andrew G. Haldane, and Benjamin D. Nelson. 2015. 'Curbing the Credit Cycle'. The Economic Journal 125 (585): 1072-1109. https://doi.org/10.1111/ecoj.12113.

Aizenman, Joshua, and Yothin Jinjarak. 2014. 'Real Estate Valuation, Current Account and Credit Growth Patterns, before and after the 2008-9 Crisis'. Journal of International Money and Finance 48 (November): 249-70. https://doi.org/10.1016/j.jimonfin.2014.05.016.

Ansell, Ben. 2014. 'The Political Economy of Ownership: Housing Markets and the Welfare State'. American Political Science Review 108 (02): 383-402. https://doi.org/10.1017/S0003055414000045.

Arcand, Jean Louis, Enrico Berkes, and Ugo Panizza. 2015. 'Too Much Finance?' Journal of Economic Growth 20 (2): 105-48. https://doi.org/10.1007/s10887-015-9115-2.

Arestis, Philip, and Ana Rosa González. 2014. 'Bank Credit and the Housing Market in OECD Countries'. Journal of Post Keynesian Economics 36 (3): 467-90. https://doi.org/10.2753/PKE0160-3477360304.

Arrighi, Giovanni. 1994. The Long Twentieth Century. London: Verso.

Arundel, Rowan. 2017. 'Equity Inequity: Housing Wealth Inequality, Inter and IntraGenerational Divergences, and the Rise of Private Landlordism'. Housing, Theory and Society 34 (2): 176-200. https://doi.org/10.1080/14036096.2017.1284154.

Badarinza, Cristian, and Tarun Ramadorai. 2018. 'Home Away from Home? Foreign Demand and London House Prices'. Journal of Financial Economics 130 (3): 53255. https://doi.org/10.1016/j.jfineco.2018.07.010.

Barrell, Ray, E. Philip Davis, Dilruba Karim, and Iana Liadze. 2010. 'Bank Regulation, Property Prices and Early Warning Systems for Banking Crises in OECD Countries'. Journal of Banking \& Finance 34 (9): 2255-64. https://doi.org/10.1016/j.jbankfin.2010.02.015.

Basu, Deepankar. 2018. 'Marx's Analysis of Ground-Rent: Theory, Examples and Applications'. UMass Amherst Economics Department Working Papers No 241. University of Massachusetts Amherst, Department of Economics.

Bernanke, Ben S., Mark Gertler, and Simon Gilchrist. 1999. 'The Financial Accelerator in a Quantitative Business Cycle Framework'. In Handbook of Macroeconomics, edited by John B. Taylor and Michael Assous, 1341-92. North-Holland.

Berry, Michael. 1986. 'Housing Provision and Class Relations under Capitalism: Some Implications of Recent Marxist Class Analysis'. Housing Studies 1 (2): 109-21. https://doi.org/10.1080/02673038608720568. . 2014. 'Housing Provision and Class Relations Under Capitalism: Comment on Christophers and Aalbers'. Housing, Theory and Society 31 (4): 395-403. https://doi.org/10.1080/14036096.2014.947079.

Bezemer, Dirk. 2014. 'Schumpeter Might Be Right Again: The Functional Differentiation of Credit'. Journal of Evolutionary Economics 24 (5): 935-50. https://doi.org/10.1007/s00191-014-0376-2. 
Bezemer, Dirk, Maria Grydaki, and Lu Zhang. 2016. 'More Mortgages, Lower Growth?' Economic Inquiry 54 (1): 652-74. https://doi.org/10.1111/ecin.12254.

Blackwell, Timothy, and Sebastian Kohl. 2018. 'The Origins of National Housing Finance Systems: A Comparative Investigation into Historical Variations in Mortgage Finance Regimes'. Review of International Political Economy 25 (1): 49-74. https://doi.org/10.1080/09692290.2017.1403358.

Bofinger, Peter, Sebastian Debes, Johannes Gareis, and Eric Mayer. 2013. 'Monetary Policy Transmission in a Model with Animal Spirits and House Price Booms and Busts'. Journal of Economic Dynamics and Control 37 (12): 2862-81. https://doi.org/10.1016/j.jedc.2013.08.002.

Boone, Lawrence, Claude Giorno, and Pete Richardson. 1998. 'Stock Market Fluctuations and Consumption Behaviour: Some Recent Evidence'. OECD Economics Department Working Papers 208. Paris: Organisation for Economic Cooperation and Development.

Borio, Claudio. 2012. 'The Financial Cycle and Macroeconomics: What Have We Learnt'. BIS Working Papers 395. Basel: Bank of International Settlement.

Buiter, Willem H. 2010. 'Housing Wealth Isn't Wealth'. Economics: The Open-Access, Open-Assessment E-Journal 4 (2010-22): 1. https://doi.org/10.5018/economicsejournal.ja.2010-22.

Case, Karl, Robert Shiller, and John Quigley. 2005. 'Comparing Wealth Effects: The Stock Market Versus the Housing Market'. Advances in Macroeconomics 5 (1): 1235-1235.

Christophers, Brett. 2018. The New Enclosure - The Appropriation of Public Land in Neoliberal Britain. London; New York: Verso.

Clift, Ben. 2014. Comparative Political Economy - States, Markets and Global Capitalism. Macmillan International Higher Education.

Coelho, Miguel, Sebastian Dellepiane-Avellaneda, and Vigyan Ratnoo. 2017. 'The Political Economy of Housing in England'. New Political Economy 22 (1): 31-60. https://doi.org/10.1080/13563467.2016.1195346.

Crouch, Colin. 2009. 'Privatised Keynesianism: An Unacknowledged Policy Regime'. The British Journal of Politics and International Relations 11 (3): 382-99. https://doi.org/10.1111/j.1467-856X.2009.00377.x.

De Grauwe, Paul. 2012. 'Booms and Busts in Economic Activity: A Behavioral Explanation'. Journal of Economic Behavior \& Organization 83 (3): 484-501. https://doi.org/10.1016/j.jebo.2012.02.013.

Department For Environment, Food, and Office For National Statistics. 2018. 'Living Costs and Food Survey, 2016-2017'. UK Data Service. https://beta.ukdataservice.ac.uk/datacatalogue/doi/?id=8351\#1.

Dieci, Roberto, and Frank Westerhoff. 2012. 'A Simple Model of a Speculative Housing Market'. Journal of Evolutionary Economics 22 (2): 303-29. https://doi.org/10.1007/s00191-011-0259-8.

Drehman, Mathias, Claudio Borio, and Kostas Tsatsaronis. 2012. 'Characterising the Financial Cycle: Don't Lose Sight of the Medium Term!' BIS Working Papers 380. Basel: Bank of International Settlement.

Dutt, Amitava Krishna. 2006. 'Maturity, Stagnation and Consumer Debt: A Steindlian Approach'. Metroeconomica 57 (3): 339-64. https://doi.org/10.1111/j.1467999X.2006.00246.x.

Edel, Matthew. 1982. 'Home Ownership and Working Class Unity'. International Journal of Urban and Regional Research 6 (2): 205-22. https://doi.org/10.1111/j.14682427.1982.tb00574.x. 
Eggertsson, Gauti B., and Paul Krugman. 2012. 'Debt, Deleveraging, and the Liquidity Trap: A Fisher-Minsky-Koo Approach*'. The Quarterly Journal of Economics 127 (3): 1469-1513. https://doi.org/10.1093/qje/qjs023.

Erturk, Ismail, and Stefano Solari. 2007. 'Banks as Continuous Reinvention'. New Political Economy 12 (3): 369-88. https://doi.org/10.1080/13563460701485599.

Fallis, george. 1985. Housing Economics. Toronto and Vancouver: Butterworth \& Co.

Fernandez, Rodrigo, and Manuel B. Aalbers. 2017. 'Housing and Capital in the Twenty-First Century: Realigning Housing Studies and Political Economy'. Housing, Theory and Society 34 (2): 151-58. https://doi.org/10.1080/14036096.2017.1293379.

Fessler, Pirmin, and Martin Schürz. 2018. 'The Functions of Wealth: Renters, Owners and Capitalists across Europe and the United States'. WP Österreichisch Nationalbank 223. Vienna: Österreichische Nationalbank.

Glaeser, Edward L. 2013. 'A Nation of Gamblers: Real Estate Speculation and American History'. American Economic Review: Papers \& Proceedings 103 (3): 1-42. https://doi.org/10.1257/aer.103.3.1.

Godley, Wynne. 1999. 'Seven Unsustainable Processes'. Levy Institute Special Report. New York: Levy Institute. http://www.levyinstitute.org/pubs/sevenproc.pdf.

Godley, Wynne, and Marc Lavoie. 2007. Monetary Economics. New York: Palgrave Macmillan.

Goodhart, C., and B. Hofmann. 2008. 'House Prices, Money, Credit, and the Macroeconomy'. Oxford Review of Economic Policy 24 (1): 180-205. https://doi.org/10.1093/oxrep/grn009.

Hancock, Lynn, and Gerry Mooney. 2013. "Welfare Ghettos" and the "Broken Society": Territorial Stigmatization in the Contemporary UK'. Housing, Theory and Society 30 (1): 46-64. https://doi.org/10.1080/14036096.2012.683294.

Harvey, David. 1974. 'Class-Monopoly Rent, Finance Capital and the Urban Revolution'. Regional Studies 8 (3-4): 239-55. https://doi.org/10.1080/09595237400185251. . 1982. 'Labor, Capital, and Class Struggle around the Built Environment in Advanced Capitalist Societies'. In Classes, Power, and Conflict, edited by Anthony Giddens and David Held, 545-61. London and Basingstoke: Macmillan.

Hasan, Mohammad S, and Majid Taghavi. 2002. 'Residential Investment, Macroeconomic Activity and Financial Deregulation in the UK: An Empirical Investigation'. Journal of Economics and Business 54 (4): 447-62. https://doi.org/10.1016/S01486195(02)00093-0.

IMF. 2000. 'Asset Prices and the Business Cycle'. Chapter 3 of World Economic Outlook. Washington, D.C.: International Monetary Fund.

Jordà, Òscar, Moritz Schularick, and Alan M. Taylor. 2016. 'The Great Mortgaging: Housing Finance, Crises and Business Cycles'. Economic Policy 31 (85): 107-52. https://doi.org/10.1093/epolic/eiv017.

Kapeller, Jakob, and Bernhard Schütz. 2014. 'Debt, Boom, Bust: A Theory of MinskyVeblen Cycles'. Journal of Post Keynesian Economics 36 (4): 781-814. https://doi.org/10.2753/PKE0160-3477360409.

Kemp, Peter A. 2015. 'Private Renting After the Global Financial Crisis'. Housing Studies 30 (4): 601-20. https://doi.org/10.1080/02673037.2015.1027671.

Kim, Yun K., Gilberto Tadeu Lima, and Mark Setterfield. 2017. 'Political Aspects of Household Debt'. Working Papers 1724. New School for Social Research, Department of Economics.

Kindleberger, Charles P. 1993. A Financial History of Western Europe. 2nd ed. Oxford: Oxford University Press. 
Knoll, Katharina, Moritz Schularick, and Thomas Steger. 2017. 'No Price Like Home: Global House Prices, 1870-2012'. American Economic Review 107 (2): 331-53. https://doi.org/10.1257/aer.20150501.

Kohl, Sebastian. 2018. 'More Mortgages, More Homes? The Effect of Housing Financialization on Homeownership in Historical Perspective'. Politics \& Society 46 (2): 177-203. https://doi.org/10.1177/0032329218755750.

Langley, Paul. 2007. 'Uncertain Subjects of Anglo-American Financialization'. Cultural Critique, no. 65: 67-91.

Lavoie, Marc, and Engelbert Stockhammer. 2013. Wage-Led Growth. An Equitable Strategy for Economic Recovery. London: Palgrave MacMillan.

Levine, Ross. 1997. 'Financial Development and Economic Growth: Views and Agenda'. Journal of Economic Literature 35 (2): 688-726.

Maki, Dean M., and Michael G. Palumbo. 2001. 'Disentangling the Wealth Effect: A Cohort Analysis of Household Saving in the 1990s'. Finance and Economics Discussion Series 2001-21. Board of Governors of the Federal Reserve System.

Mian, Atif, Kamalesh Rao, and Amir Sufi. 2013. 'Household Balance Sheets, Consumption, and the Economic Slump*'. The Quarterly Journal of Economics 128 (4): 1687-1726. https://doi.org/10.1093/qje/qjt020.

Mian, Atif, and Amir Sufi. 2018. 'Finance and Business Cycles: The Credit-Driven Household Demand Channel'. Journal of Economic Perspectives 32 (3): 31-58. https://doi.org/10.1257/jep.32.3.31.

Minsky, Hyman P. 1978. 'The Financial Instability Hypothesis: A Restatement'. Paper 180. Hyman P. Minsky Archive.

Muellbauer, John. 2007. 'Housing, Credit and Consumer Expenditure'. Proceedings Economic Policy Symposium - Jackson Hole. Federal Reserve Bank of Kansas City.

Office For National Statistics, Social Survey Division. 2018. 'Wealth and Assets Survey, Waves 1-5, 2006-2016'. UK Data Service. https://beta.ukdataservice.ac.uk/datacatalogue/doi/?id=7215\#7.

Palley, Thomas I. 1994. 'Debt, Aggregate Demand, and The Business Cycle: An Analysis in the Spirit of Kaldor and Minsky'. Journal of Post Keynesian Economics 16 (3): 37190. https://doi.org/10.1080/01603477.1994.11489991.

Park, Joon. 2014. 'Land Rent Theory Revisited'. Science \& Society 78 (1): 88-109.

Perugini, Cristiano, Jens Hölscher, and Simon Collie. 2016. 'Inequality, Credit and Financial Crises'. Cambridge Journal of Economics 40 (1): 227-57. https://doi.org/10.1093/cje/beu075.

Poulantzas, Nicos. 1982. 'On Social Classes'. In Classes, Power, and Conflict, edited by Anthony Giddens and David Held, 101-11. London and Basingstoke: Macmillan.

Ryan-Collins, Josh, Toby Lloyd, and Laurie MacFarlane. 2017. Rethinking the Economics of Land and Housing. London: Zed Books.

Ryoo, Soon. 2016. 'Household Debt and Housing Bubbles: A Minskian Approach to BoomBust Cycles'. Journal of Evolutionary Economics 26 (5): 971-1006. https://doi.org/10.1007/s00191-016-0473-5.

Saunders, Peter. 1984. 'Beyond Housing Classes: The Sociological Significance of Private Property Rights in Means of Consumption'. International Journal of Urban and Regional Research 8 (2): 202-27. https://doi.org/10.1111/j.14682427.1984.tb00608.x.

Schwartz, Herman, and Leonard Seabrooke. 2008. 'Varieties of Residential Capitalism in the International Political Economy: Old Welfare States and the New Politics of Housing'. Comparative European Politics 6 (3): 237-61. https://doi.org/10.1057/cep.2008.10. 
Shaikh, Anwar. 2016. Capitalism Competition, Conflict, Crises. Oxford: Oxford University Press.

Slacalek, Jiri. 2009. 'What Drives Personal Consumption? The Role of Housing and Financial Wealth'. The B.E. Journal of Macroeconomics 9 (1). https://doi.org/10.2202/1935-1690.1555.

Soaita, Adriana Mihaela, Beverley Ann Searle, Kim McKee, and Tom Moore. 2017. 'Becoming a Landlord: Strategies of Property-Based Welfare in the Private Rental Sector in Great Britain'. Housing Studies 32 (5): 613-37. https://doi.org/10.1080/02673037.2016.1228855.

Stiglitz, Joseph E., and Andrew Weiss. 1981. 'Credit Rationing in Markets with Imperfect Information'. The American Economic Review 71 (3): 393-410.

Stockhammer, Engelbert. 2012. 'Financialization, Income Distribution and the Crisis'. Investigación Económica 71 (279): 39-70.

Stockhammer, Engelbert, and Rafael Wildauer. 2016. 'Debt-Driven Growth? Wealth, Distribution and Demand in OECD Countries'. Cambridge Journal of Economics 40 (6): 1609-34. https://doi.org/10.1093/cje/bev070.

Watson, Matthew. 2010. 'House Price Keynesianism and the Contradictions of the Modern Investor Subject'. Housing Studies 25 (3): 413-26. https://doi.org/10.1080/02673031003711550.

Wood, James D. G. 2017. 'The Integrating Role of Private Homeownership and Mortgage Credit in British Neoliberalism'. Housing Studies, December, 1-21. https://doi.org/10.1080/02673037.2017.1414159. 
Table 1. Distribution of tenure types in the UK, 2014-16

\begin{tabular}{|l|c|c|c|}
\hline & $\begin{array}{c}\text { No. observations } \\
\text { (sample size) }\end{array}$ & $\begin{array}{c}\text { weighted No. of observations } \\
\text { (population size) }\end{array}$ & $\begin{array}{c}\text { \% of total } \\
\text { population }\end{array}$ \\
\hline Total & 18,611 & $25,602,086$ & $100.0 \%$ \\
Renters & 4,688 & $8,381,300$ & $32.7 \%$ \\
Owner-outright & 7,467 & $7,835,424$ & $30.2 \%$ \\
Owner-mortgage & 4,777 & $7,750,106$ & $29.9 \%$ \\
Rentiers & 1,679 & $1,635,256$ & $6.4 \%$ \\
\hline
\end{tabular}

Calculations based on Wealth and Assets Survey, Wave 5, 2014-2016 
Table 2. Average income by tenure type

\begin{tabular}{|c|c|c|c|c|c|}
\hline & tot. inc. ${ }^{\mathrm{i}}$ & emp. inc. ${ }^{\text {ii }}$ & emp. inc. (ex. pen.) ${ }^{\mathrm{iii}}$ & inc. rent ${ }^{\mathrm{iv}}$ & inc. invst. $^{\mathrm{v}}$ \\
\hline Renter & 23,465 & 12,861 & 14,319 & 54 & 195 \\
\hline Owner-mortgage & 43,860 & 35,972 & 37,568 & 0 & 509 \\
\hline Owner-outright & 32,214 & 10,954 & 23,308 & 0 & 2,391 \\
\hline Rentier & 63,479 & 32,031 & 42,702 & 13,061 & 3,272 \\
\hline \multicolumn{6}{|c|}{$\begin{array}{l}\text { i) Mean Household Total Regular Annual Income } \\
\text { ii) Mean Household Annual Employment Income } \\
\text { ld Annual Employment Income, excluding pensioners } \\
\text { iv) Mean Household Annual Income from Rent } \\
\text { v) Mean Household Annual Income from Investment }\end{array}$} \\
\hline
\end{tabular}


Table 3. Net rent as share of normal household weekly disposable income, 2016-17

\begin{tabular}{|c|c|c|}
\hline Decile & renter-private & renter-social \\
\hline 1 (poorest) & $41 \%$ & $13 \%$ \\
2 & $37 \%$ & $10 \%$ \\
3 & $28 \%$ & $13 \%$ \\
4 & $24 \%$ & $12 \%$ \\
5 & $26 \%$ & $14 \%$ \\
6 & $26 \%$ & $11 \%$ \\
7 & $21 \%$ & $13 \%$ \\
8 & $19 \%$ & $9 \%$ \\
9 & $21 \%$ & $9 \%$ \\
10 (richest) & $21 \%$ & $5 \%$ \\
\hline
\end{tabular}




\section{Appendix}

Table A1. Distribution of profession by tenure type

\begin{tabular}{|l|c|c|c|c|}
\hline Profession & Renter & $\begin{array}{c}\text { Owner- } \\
\text { outright }\end{array}$ & $\begin{array}{c}\text { Owner- } \\
\text { mortgage }\end{array}$ & Rentier \\
\hline Managerial \& prof. occupations & $22 \%$ & $44 \%$ & $56 \%$ & $62 \%$ \\
Intermediate occupations & $18 \%$ & $23 \%$ & $19 \%$ & $24 \%$ \\
Routine \& manual occupations & $50 \%$ & $32 \%$ & $24 \%$ & $13 \%$ \\
Never worked/long term unemp. & $7 \%$ & $1 \%$ & $0 \%$ & $0 \%$ \\
Not classified & $3 \%$ & $0 \%$ & $1 \%$ & $1 \%$ \\
\hline
\end{tabular}

Calculations based on Wealth and Assets Survey, Wave 5, 2014-2016

Table A2. Age distribution by tenure type

\begin{tabular}{|l|c|c|c|c|}
\hline Age band & Renter & Owner-outright & Owner-mortgage & Rentier \\
\hline $16-24$ & $4 \%$ & $0 \%$ & $0 \%$ & $0 \%$ \\
$25-34$ & $21 \%$ & $1 \%$ & $18 \%$ & $8 \%$ \\
$35-44$ & $20 \%$ & $2 \%$ & $30 \%$ & $20 \%$ \\
$45-54$ & $20 \%$ & $9 \%$ & $32 \%$ & $24 \%$ \\
$55-64$ & $13 \%$ & $23 \%$ & $14 \%$ & $25 \%$ \\
$65-74$ & $11 \%$ & $31 \%$ & $3 \%$ & $17 \%$ \\
$75-84$ & $7 \%$ & $24 \%$ & $1 \%$ & $5 \%$ \\
$85+$ & $4 \%$ & $9 \%$ & $0 \%$ & $2 \%$ \\
\hline \multicolumn{5}{|r|}{ Calculations based on Wealth and Assets Survey, Wave 5, 2014-2016 } \\
\hline
\end{tabular}

Table A3. Tenure Types based on Living Cost and Food Survey

Other $1.2 \%$

Owner mortgage $\quad 31.2 \%$

Owner outright $\quad 35.4 \%$

Renter-private $\quad 16.2 \%$

Renter-social $16.0 \%$

Calculations based on UK Living Costs and Food Survey, 2016-2017 
Table A4. Net housing costs/ normal weekly disposable income

\begin{tabular}{|c|c|c|c|c|}
\hline Decile & private-renter & renter-social & owner-outright & owner-mortgage \\
\hline 1 & $57 \%$ & $23 \%$ & $23 \%$ & $80 \%$ \\
2 & $45 \%$ & $17 \%$ & $14 \%$ & $27 \%$ \\
3 & $38 \%$ & $21 \%$ & $13 \%$ & $26 \%$ \\
4 & $30 \%$ & $20 \%$ & $11 \%$ & $18 \%$ \\
5 & $33 \%$ & $22 \%$ & $10 \%$ & $18 \%$ \\
6 & $31 \%$ & $17 \%$ & $9 \%$ & $16 \%$ \\
7 & $27 \%$ & $17 \%$ & $8 \%$ & $14 \%$ \\
8 & $25 \%$ & $13 \%$ & $7 \%$ & $13 \%$ \\
9 & $26 \%$ & $13 \%$ & $6 \%$ & $12 \%$ \\
10 & $24 \%$ & $9 \%$ & $5 \%$ & $13 \%$ \\
\hline \multicolumn{4}{|r|}{ Calculations based on UK Living Costs and Food Survey, 2016-2017 } \\
\hline
\end{tabular}

